UDC 556.535

Svitlana Ivanivna Reshetchenko,

$\mathrm{PhD}$ (Geography), Associate Professor, Department of Physical Geography and Cartography,

Faculty of Geology, Geography, Recreation and Tourism, V. N. Karazin Kharkiv National University,

4 Svobody Sq., Kharkiv, 61022, Ukraine,

e-mail: s.reshetchenko@karazin.ua, https://orcid.org/0000-0003-0744-4272;

Sviatoslav Stanislavovych Dmitriiev,

Bachelor, V. N. Karazin Kharkiv National University,

e-mail: xa13278062@,student.karazin.ua, https://orcid.org/0000-0001-9256-6455;

Nadiia Ivanivna Cherkashyna,

Senior Lecturer, V. N. Karazin Kharkiv National University,

e-mail: n.cherka@gmail.com, https://orcid.org/0000-0002-4066-2530;

Liudmyla Dmytrivna Goncharova,

$\mathrm{PhD}$ (Geography), Associate Professor, Odessa State Environmental University,

5-b Ak. Glushko Av., apt. 92, Odessa, 65113, Ukraine,

goncharova.luda.50@gmail.com, https://orcid.org/0000-0002-6340-2424

\title{
CLIMATE INDICATORS OF CHANGES IN HYDROLOGICAL CHARACTERISTICS (A CASE OF THE PSYOL RIVER BASIN)
}

С. І. Решетченко, С. С. Дмітрієв, Н. І. Черкашина, Л. Д. Гончарова. КЛІМАТИЧНІ ПОКАЗНИКИ ЯК ІНДИФІКАТОРИ ЗМІН ГІДРОЛОГІЧНИХ ХАРАКТЕРИСТИК НА ПРИКЛАДІ БАСЕЙНУ РІЧКИ ПСЕЛ. У статті подається аналіз впливу кліматичних показників на основні гідрологічні характеристики на прикладі басейну річки Псел в межах України. Розробка начіональної кліматичної програми та відповідність Угоді про асоџіацію між Украӥною та ЄС спрямовані на довготермінові заходи з адаптаиії до змін клімату, де передбачено розроблення законодавчої бази у сфері охорони довкілля, галузевих стратегій щодо покращення якості повітря, води. Ці заходи потребують ідентифікації впливу кліматичних факторів на гідрологічні характеристики водних об'єктів будь-якої території з метою їх охорони, покращення та комплексного підходу до раціонального управління водними ресурсами.

Сучасні зміни кліматичних умов на території України характеризуються локальністю та стрімкістю: зростання кількості аномальних атмосферних явищ, частоти появи посух, суховїв, що може спричинити за попередніми оцінками зменшення водних ресурсів, зміни внутрішнього річного перерозподілу температури води та стоку на фоні зростання термічних ресурсів території. Основними завданнями дослідження є визначення взаємозв'язків між кліматичними та гідрологічними показниками басейну річки Псел та можливих їх проєкиій. Аналіз кліматичних змін у басейні річки Псел вказує на зменшення витрат води як у головній річці басейну, так і у ї̈ основних притоках. Окрім змін температурно-вологісного режиму, причинами иього прочесу стали зміщення, що відбулися у характері внутрішньорічного розподілу стоку. Протягом кіния XX - початку XXI століття частка весняного водопілля знизилася за рахунок зменшення тривалості періоду льодових явищ та відповідного зменшення потужності снігового покриву на річках. Як наслідок, найважливіша складова річного стоку річок стала стрімко зменшуватися, $і$ на фоні переважного зменшення кількості атмосферних опадів, роль підземних вод у формуванні водного стоку має зростати. Особливо ие актуально для середніх та малих річок, які зазнають значного антропогенного навантаження: зарегульованість русел, створення штучних озер, їх обміління.

Дослідження впливу змін кліматичних показників на гідрологічні характеристики дає можливість визначити референиійні умови та класи екологічного стану річок за умов антропогенного навантаження на тлі подальших змін кліматичних показників, що матимуть різноспрямовані тенденції.

Ключові слова: поверхневі води, внутрішні води, річковий басейн, моніторинг, аналіз річкових басейнів, клімат, зміни клімату, антропогенне навантаження.

С. И. Решетченко, С. С. Дмитриев, Н. И. Черкашина, Л. Д. Гончарова. КЛИМАТИЧЕСКИЕ ПОКАЗАТЕЛИ КАК ИНДИФИКАТОРЫ ИЗМЕНЕНИЙ ГИДРОЛОГИЧЕСКИХ ХАРАКТЕРИСТИК НА ПРИМЕРЕ БАССЕЙНА РЕКИ ПСЕЛ. В статье представлен анализ влияния климатических показателей на основные гидрологические характеристики на примере бассейна реки Псел в пределах Украины. Работа над национальной климатической программой и соответствие Соглашению об ассочиации между Украиной и ЕС направлены на долгосрочные мероприятия по вопросам адаптации $к$ изменениям климата, где предусмотрены проекты законодательной базы в сфере охраны окружающей среды, отраслевых стратегий с иелью улучшения качества воды, воздуха. Эти мероприятия требуют идентификации влияния климатических факторов на гидрологические характеристики водных объектов разной территории с иелью их охрань, улучшения и комплексного подхода рационального управления водными ресурсами.

Современные изменения климатических условий на территории Украины характеризуются локальностью и резкостью: увеличивается количество аномальных атмосферных явлений, частота засух, суховеи, которые могут способствовать за предыдущиим оценками уменьшению водных ресурсов, изменениям внутригодового перераспределение температуры воды и стока на фоне увеличения температурных ресурсов территории. Основными задачами исследования являются взаимосвязи между климатическими и гидрологическими показателями бассейна реки Псел, а также их возможные проекиии. Анализ климатических изменений в бассейне реки Псел показывает уменьшение расхода воды как в основном русле бассейна, так и в его притоках. Кроме изменений температурно-влажностного режима территории, причинами этого процесса являются сдвиги, которые наблюдаются в годовом внутреннем распределении стока.

В течение кониа XX - начала XXI века часть весеннего наводнения уменьшилась за счет уменьшения продолжительности ледниковых явлений и соответственно интенсивности снежного покрова на реках. Как следствие, главная составляющая годового стока рек стала стремительно уменьшаться, и на фоне преобладающего уменьшения количества атмо(C) Reshetchenko S. I., Dmitriiev S. S., Cherkashyna N. I., Goncharova L. D., 2020 
сферных осадков, значение подземных вод в формировании водного потока должно увеличиваться. Особенно это важно для средних и мальх рек, которые страдают от антропогенного давления: зарегулированности русел, создания искусственных озер, их обмеления.

Исследования влияния изменений климатических показателей на гидрологические характеристики дают возможность определять референтные условия и классы экологического состояния рек при условии антропогенного давления на фоне дальнейших изменений климатических показателей, которые имеют разнонаправленные тенденции.

Ключевые слова: поверхностные воды, внутренние воды, речной бассейн, мониторинг, анализ речных бассейнов, климат, изменения климата, антропогенная нагрузка.

Formulation of the problem. Changes in the global climate system [18] have become apparent not only to scientists but also to government officials (Paris Agreement, 2015, UN Climate Negotiations, 2018, Katowice, Poland), having focused their attention on global climate policy, implemented at the national and regional levels. The concept of implementing state policy in the field of climate change for the period up to 2030 [15] aims to develop a national climate program, to prevent climate change and reduce the risks associated with it. Changes in climatic conditions in Ukraine are characterized by locality and rapidity: growth of abnormal atmospheric phenomena, frequency of droughts, floods, changes in the internal annual redistribution of air and water temperatures, runoff and precipitation $[3,5,14]$.

The Association Agreement between Ukraine and the EU is aimed at long-term adaptation measures to climate change, providing for the development of legislation in the field of environmental protection, sectoral strategies to improve air and water quality. The EU Water Framework Directive $[1,19-20]$ aims to protect all waters, promote the sustainable use of water in the long-term protection of water resources, improving the aquatic environment and an integrated approach to sound water management. Directive 2007/60 / EC of the European Parliament and of the Council [21] on the assessment and management of floods is aimed at identifying river basins and coastal zones that may be in the floodplain.

According to the EU Water Framework Directive and the Association Agreement between Ukraine and the EU on the territory of Ukraine (2016) there is a basin principle of water resources management, which establishes nine river basin districts: the Dnieper, Don, Vistula, Dniester, Danube, Southern Bug, rivers of the Black Sea coast, Azov region and Crimea. By 2024, the country has pledged to present nine management plans for certain areas.

The country's water policy is aimed at addressing the threats posed by anthropogenic pollution, climate and hydro-morphological changes in water bodies. Research on quantitative and qualitative indicators of anthropogenic impact on water bodies can be used to fulfill the main commitments made by Ukraine within the signed documents and programs, in particular, to develop a strategy for envi- ronmental management of water resources and its implementation in practice.

Analysis of recent research and publications. Studies of possible changes in river runoff caused by global anthropogenic warming began in the $80 \mathrm{~s}$ of the last century and remain today one of the main tasks of hydrology [2, 4, 6, 10]. Using mathematical models of atmospheric circulation allows us to obtain generalized calculations of the average global and regional air temperature, characterized by significant errors in case of different models [6]. According to the established projections, runoff redistribution is fixed within the year: there are winter and summer hydrological seasons. In winter high runoff of rainwater is expected from November to April with maximum in March; summer (MayOctober) is characterized by lows in July-August.

Changes in water resources of Ukraine in the context of global warming are presented in $[4,6$, $10]$, where there is a tendency of water resources and runoff reduction by $25 \%$ under conditions of thermal resources increase in the climate of the territory. Variability of weather conditions in the country occurs in accordance with changes in atmospheric processes in the Atlantic-European sector [3,5,13].

Hydrological regime, hydroecological condition of the rivers Psyol and Vorskla are studied in [7-9, 11], assessing water quality by the method of ecological assessment of water quality (water pollution index) and hazard criteria (method of the "F.F. Erisman Research Institute of Hygiene"). Landscape-hydrological analysis of water regime of the country's rivers is presented in [6].

It is noted that climate is one of the main factors determining formation of the hydrological regime of water bodies.

Zoning of the catchment area of the Dnieper river by hydrological and hydrochemical characteristics during a minimal runoff period is presented in [2], where the Psyol river basin is referred to 7 districts with minimal runoff in August-September with hydrocarbonate and calcium-sodium chemical type of water.

Based on the main provisions of the national environmental policy of Ukraine on the use of water resources [12] and the implementation of European principles of the Water Framework Directive 2000/60 / EC (ERVD) [1, 19], the study of changes in hydrological regime of rivers is of practical importance for sustainable management. 
Selection of previously unsolved parts of the general problem. There are different approaches to assessing the impact of climate change on hydrological characteristics of objects and introduction of water resources zoning. The applied value here is to identify general patterns in the course of hydrological phenomena. They are aimed at preventing degradation of water resources, protecting them, developing environmental approaches in calculations and forecasts of reducing water pollution.

Climatic factors are decisive in the internal annual distribution of runoff. They affect the hydroecological status of water resources and require further research, as well as expansion of monitoring measures.

Formulation of the purpose of the article. The purpose of the study is to determine relationship between climatic and hydrological parameters of the river Psyol basin.

Research methods are presented by statistical and cartographic analysis (correlation analysis method). The initial information is the results of observations contained in the State Climate Cadastre and the State Water Cadastre for the Dnieper Valley for the period (1914) 1936-2019 and 1961-2019, respectively, as well as data on water levels obtained from the collection of papers "Information on the level water in the Dnieper basin for 1914-1930 "and water cadastres for the period 1931-1936.

Climatic indicators are represented by average monthly, monthly and annual, maximum, minimum values of air temperature, as well as monthly, annual precipitation at meteorological stations in Sumy, Gadiach, Poltava, Kobeliaky for the period 19682019.

The hydrological characteristics of the Psyol river basin are the average monthly water level in the river, monthly, annual maximum and minimum water levels for the period 1914-2017, water flow for twelve months and a year, average monthly and maximum water temperatures in the river for the period 1936 (1937) - 2017.

Presentation of the main research material. Dynamics of climatic and hydrological values is analysed by means of indicators' averaging for a month or for a year. Since meteorological and hydrological indicators are a series of random variables, we consider them part of the general totality.

A correlation coefficient (the Fisher's correlation coefficient) is used to mathematically substantiate the degree of relationship between air and water temperature, as well as between rainfall and river water level, calculated for the areas where the hydropost and a meteorological station are as close as possible - Sumy, Gadiach, a meteorological station of Kobeliaky - Zapsillya hydropost. The value of the coefficient ranges from -1 to 1 . If the value of the coefficient is below zero, the relationship is inverse, if between 0 and 0.2 - almost absent, $0.2-$ 0.5 - weak, $0.5-0,7$ - medium, $0.7-1.0$ - strong.

To verify the significance of the Fisher's correlation coefficients in mathematical statistics, the Student's test is used, calculated by formula (1):

$$
\mathrm{t} *=\mathrm{r} / \sigma \mathrm{r},
$$

where $\mathrm{t} *$ is the Student's $\mathrm{t}$ test, $\mathrm{r}$ is the correlation coefficient, $\sigma \mathrm{r}$ is the standard error.

As WMO recommends to consider the standard climatic norm for the period 1961-1990, the climatological and hydrological statistical series are divided into two samples: 1961-1990 and 1991-2019, establishing "basic" and modern conditions, identifying the trends in their changes.

The main visual indicators in climatology are long-term series of average monthly temperatures in January and July. The trend of temperature "shift" has become noticeable over the last decades, when the coldest month gradually becomes February, and the warmest - August. The air temperature is characterized by a fairly high degree of dispersion compared to many other indicators, as it distinguishes the state of atmospheric air, which is extremely variable (Fig. 1). The tendency to its increase by $0.8^{\circ}$ $\mathrm{C}$ has been established for decades at meteorological stations of the studied area (Table 1).

Analysis of the average air temperature for the two periods of 1961-1990, 1991-2019 indicates an increase in air temperature in January and July at all weather stations (Fig. 2). In winter, intense warming was detected at the Sumy meteorological station (by $3.0^{\circ} \mathrm{C}$ ), and in summer - at the Gadiach meteorological station (by $2.0^{\circ} \mathrm{C}$ ).

Spatial distribution of temperature indicators is presented in Fig. 3. There was an increase in air temperature throughout the basin in January in the south-western direction, reaching maximum levels in the lower parts of the river. There is a latitudinal pattern of air temperature growth in July where maximum values are concentrated in the central part of the river basin.

The analysis of seasonal temperature indicators also established a tendency to its growth with different intensity at all meteorological stations of the studied territory (Fig. 4).

A generalized assessment of climate change can be obtained by analyzing the average annual air temperatures which smooth out all intra-annual fluctuations (Fig. 5). On the example of air temperature dynamics at the meteorological station Gadiach we can speak about the significant amplitudes of air temperature where it increased by $1.3{ }^{\circ} \mathrm{C}$ during 1991-2019. At the meteorological stations Poltava and Kobeliaky this indicator was $1.1-1.2^{\circ} \mathrm{C}$, while at the meteorological station Sumy $-0.9^{\circ} \mathrm{C}$. 


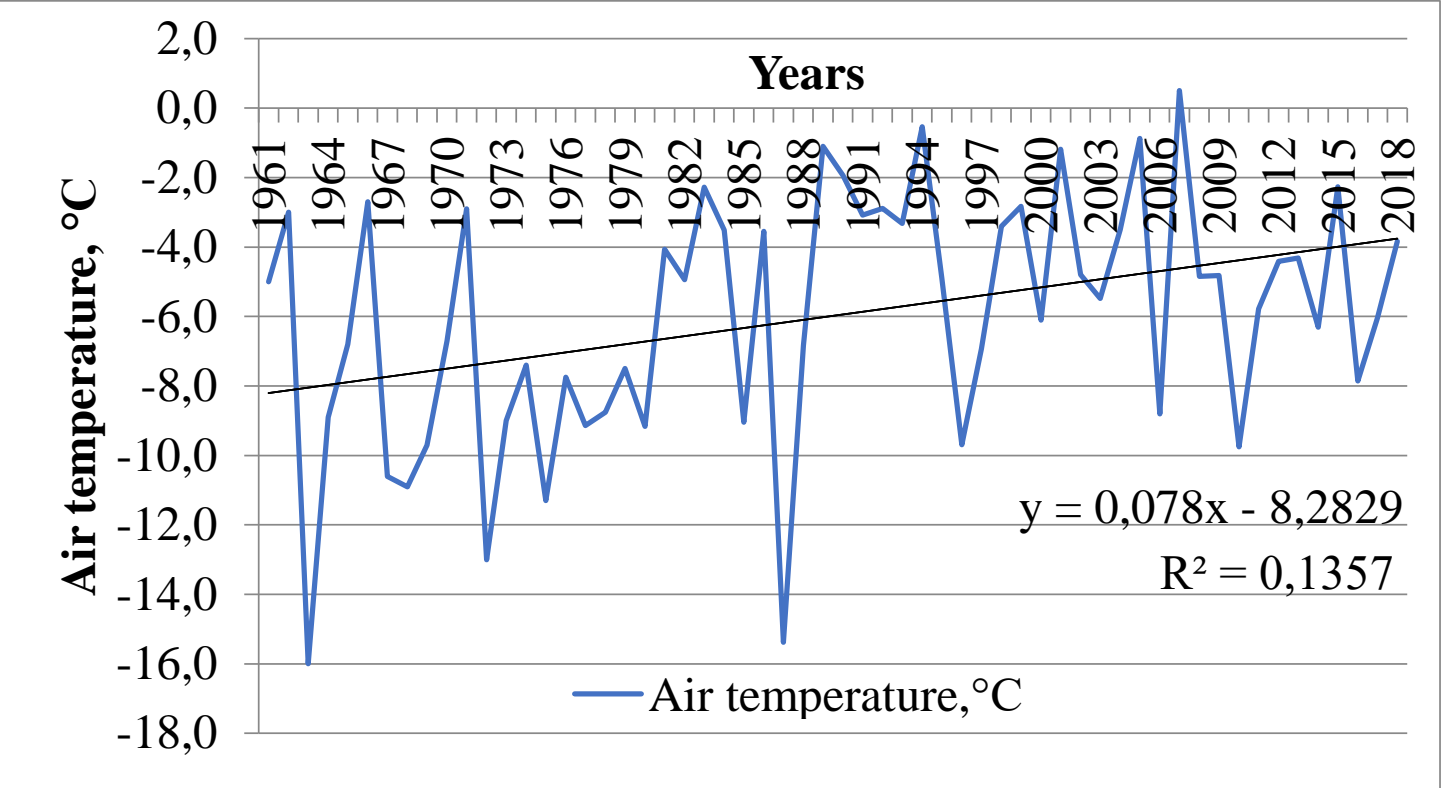

a)

b)

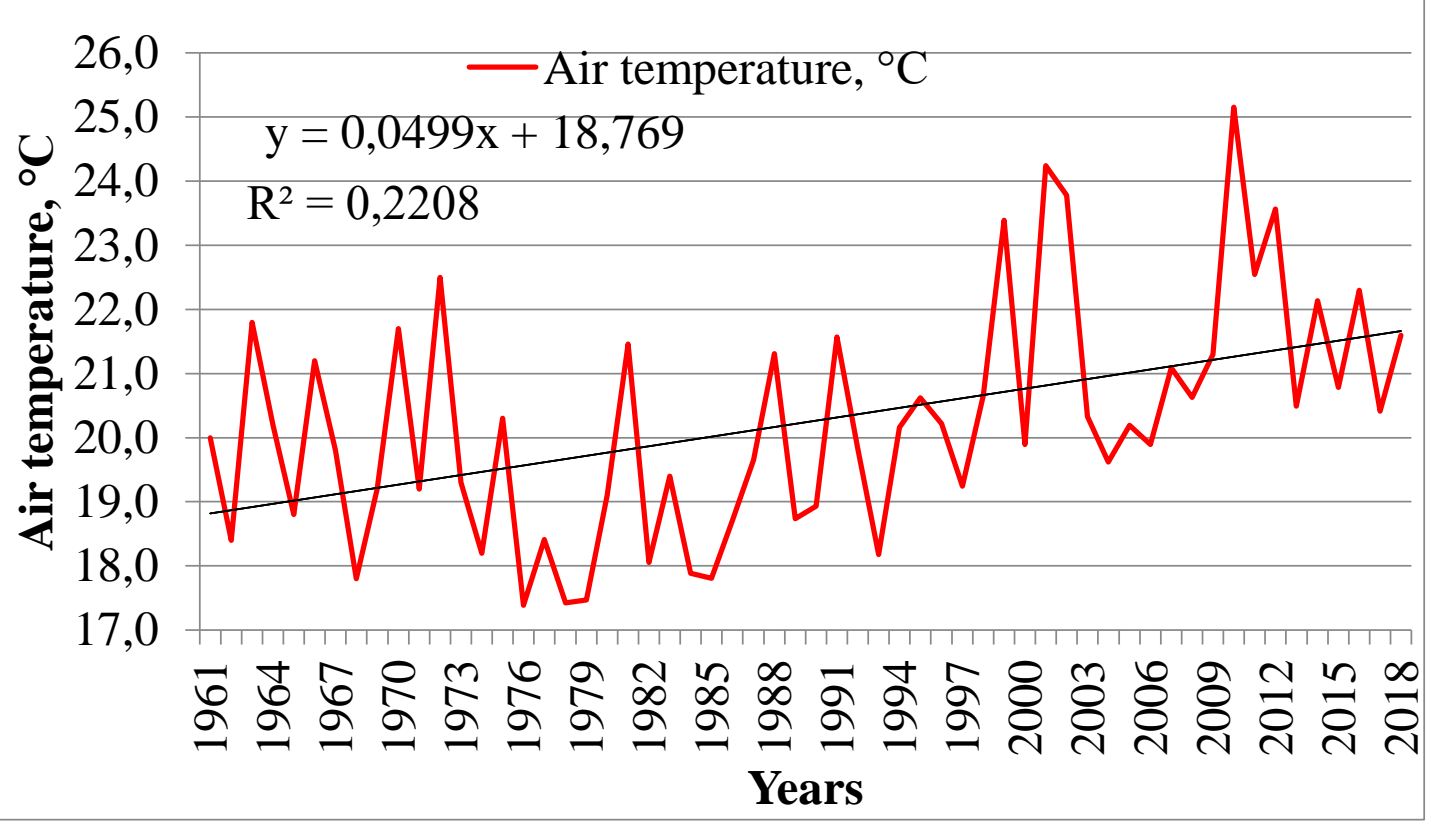

Fig. 1. Average annual air temperature in January (a) at the meteorological station Gadiach in July (b) for the period 1961-2019

Table 1

Average annual air temperatures in January (July) for 1961-2019

\begin{tabular}{|c|c|c|c|c|}
\hline \multirow{2}{*}{$\begin{array}{c}\text { Meteorological } \\
\text { station }\end{array}$} & \multicolumn{2}{|c|}{ Average air temperature in January, ${ }^{\circ} \mathrm{C}$} & \multicolumn{2}{|c|}{ Average air temperature in July, ${ }^{\circ} \mathrm{C}$} \\
\cline { 2 - 5 } & Tendency & Value & Tendency & Value \\
\hline Sumy & Increase & $0.8^{\circ} \mathrm{C}$ in 10 years & Increase & $0.8^{\circ} \mathrm{C}$ in 10 years \\
\hline Gadiach & Increase & $0.8^{\circ} \mathrm{C}$ in 10 years & Increase & $0.8^{\circ} \mathrm{C}$ in 10 years \\
\hline Poltava & Increase & $0.7^{\circ} \mathrm{C}$ in 10 years & Increase & $0.7^{\circ} \mathrm{C}$ in 10 years \\
\hline Kobeliaky & Increase & $0.8^{\circ} \mathrm{C}$ in 10 years & Increase & $0.8^{\circ} \mathrm{C}$ in 10 years \\
\hline
\end{tabular}

Considering the fact that under international agreements the countries have committed to keep the temperature rise in the range of $1.5-2.0{ }^{\circ} \mathrm{C}$, most weather stations are already approaching a critical level at the local level in the valley of the river Psyol.
Precipitation affects water content of rivers. Investigating the changes in the annual amount of precipitation at the meteorological stations of Sumy and Gadiach, a tendency to their decrease was revealed (Fig. 6). 


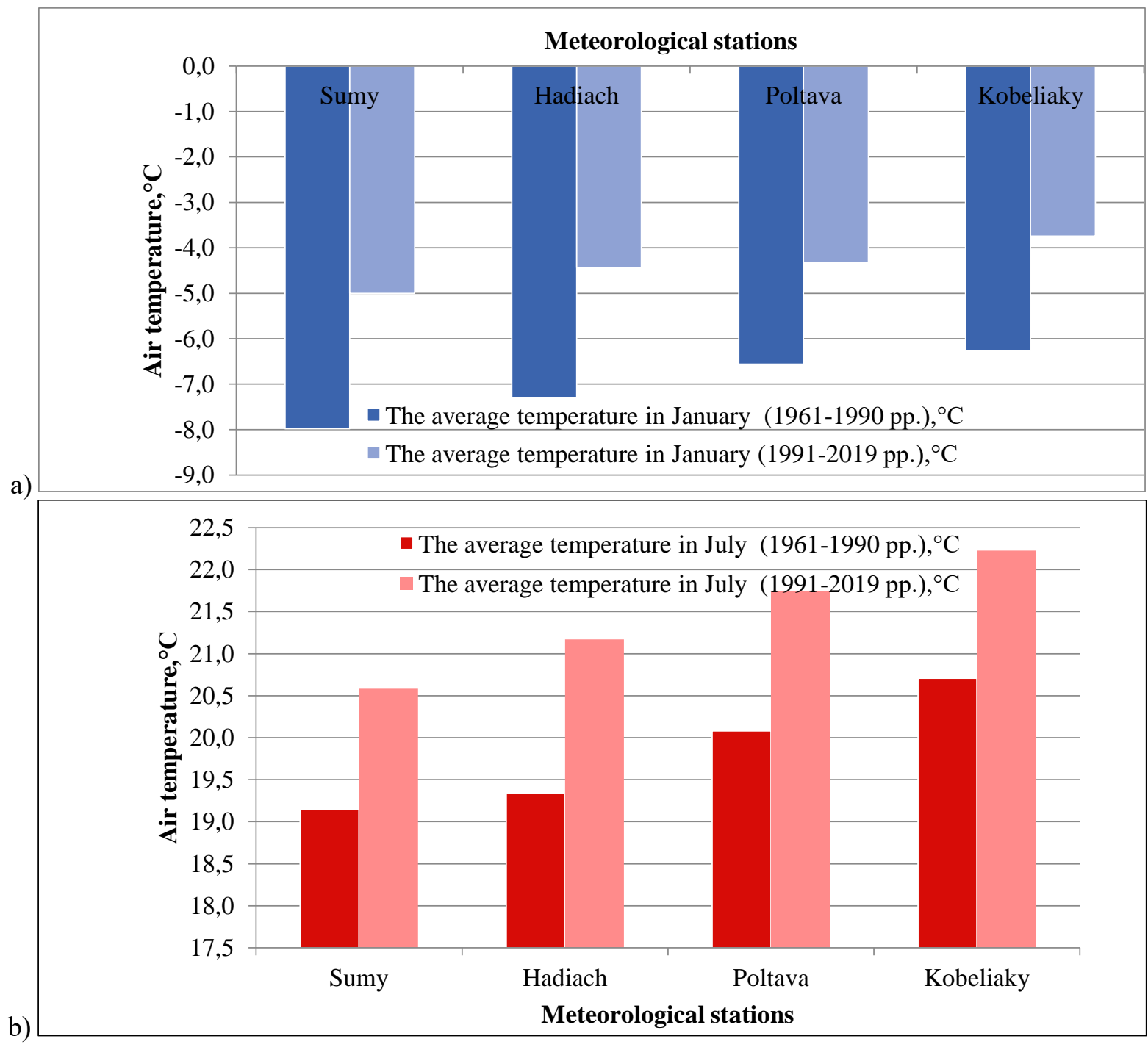

Fig. 2. Average monthly temperatures in January (a), July (b) for the periods 1961-1990, 1991-2019

At the meteorological stations Poltava and Kobeliaky they remained almost unchanged for the period 1991-2019. One of the precipitation features of the dynamics is their fluctuating nature every $2-3$ years.

Water levels and water consumption are important among the hydrological indicators of rivers. Given that the Psyol river is one of the longest left tributaries of the Dnieper, it is inferior to the catchment area of the majority of Ukrainian watercourses, flowing between two significant rivers - the Vorskla and Sula. Their basins limit it from southeast and northwest, respectively. In addition to the Psyol river itself, this study analyzes hydrological characteristics of its tributaries: the Khorol (hydropost Myrhorod) and Govtva (hydropost Mykhnivka).

According to the classification of Zaikov, the Psyol river is a typical representative of the Eastern European type, characterized by a pronounced spring flood which brings from 60 to $70 \%$ of the annual river runoff. Spring floods in March-April are clearly noticed at all hydroposts in the Psyol river basin. During May and August water consumption in rivers decreases and reaches a minimum (limited) in mid-August where the main sources of food are groundwater and precipitation. It is the presence of a significant amount of precipitation in June and July that explains the low tide only in August (Fig. 7).

Water level is generally the same as water flow as it is directly related to it: the highest level is in March-April during the spring flood.

The dynamics of the water level in the rivers Psyol 1, Khorol and Govtva for 1914 (1936) - 2017 is characterized by three periods - two relatively high-water (1914-1933, 1983-2017) and one relatively low-water - 1934-1982. (Fig. 8).

Having analyzed the annual water flow and water level fluctuations in the Psyol river and its main tributaries, we have found a tendency to decrease from May to August. Due to autumn precipitation water level rises while in winter it is almost stable. In winter the rivers flow into the glacier. Annual wa- 
a)

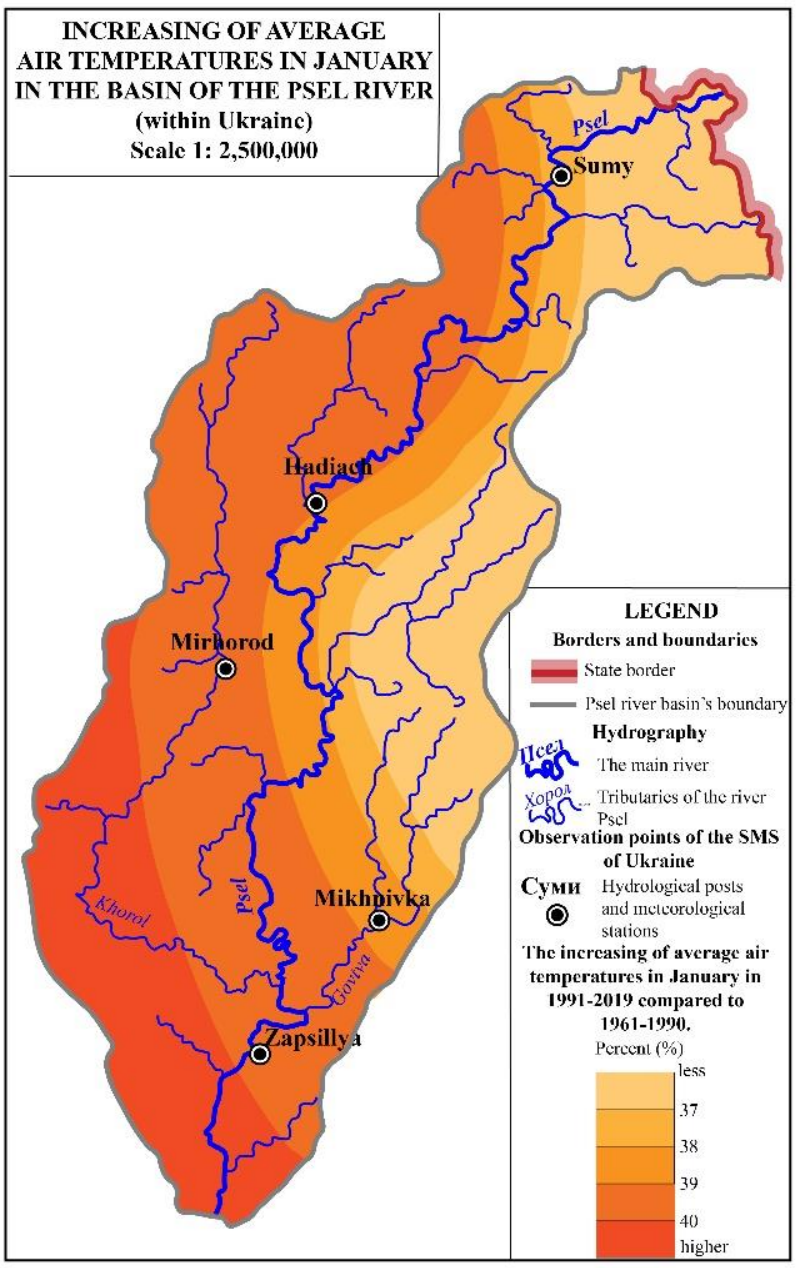

b)

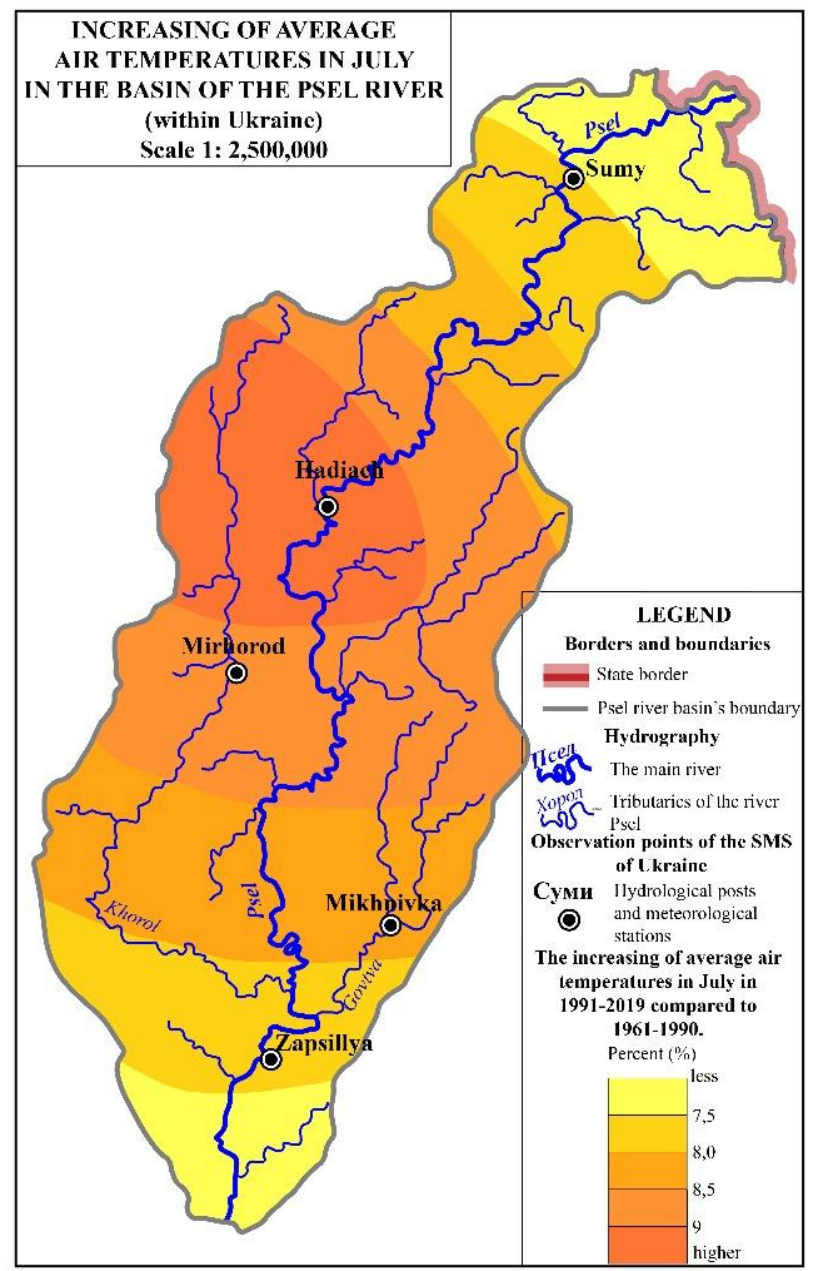

Fig. 3. Average monthly air temperature in January (a), July (b) in the basin of the river Psyol in 1991-2019 in relation to 1961-1990

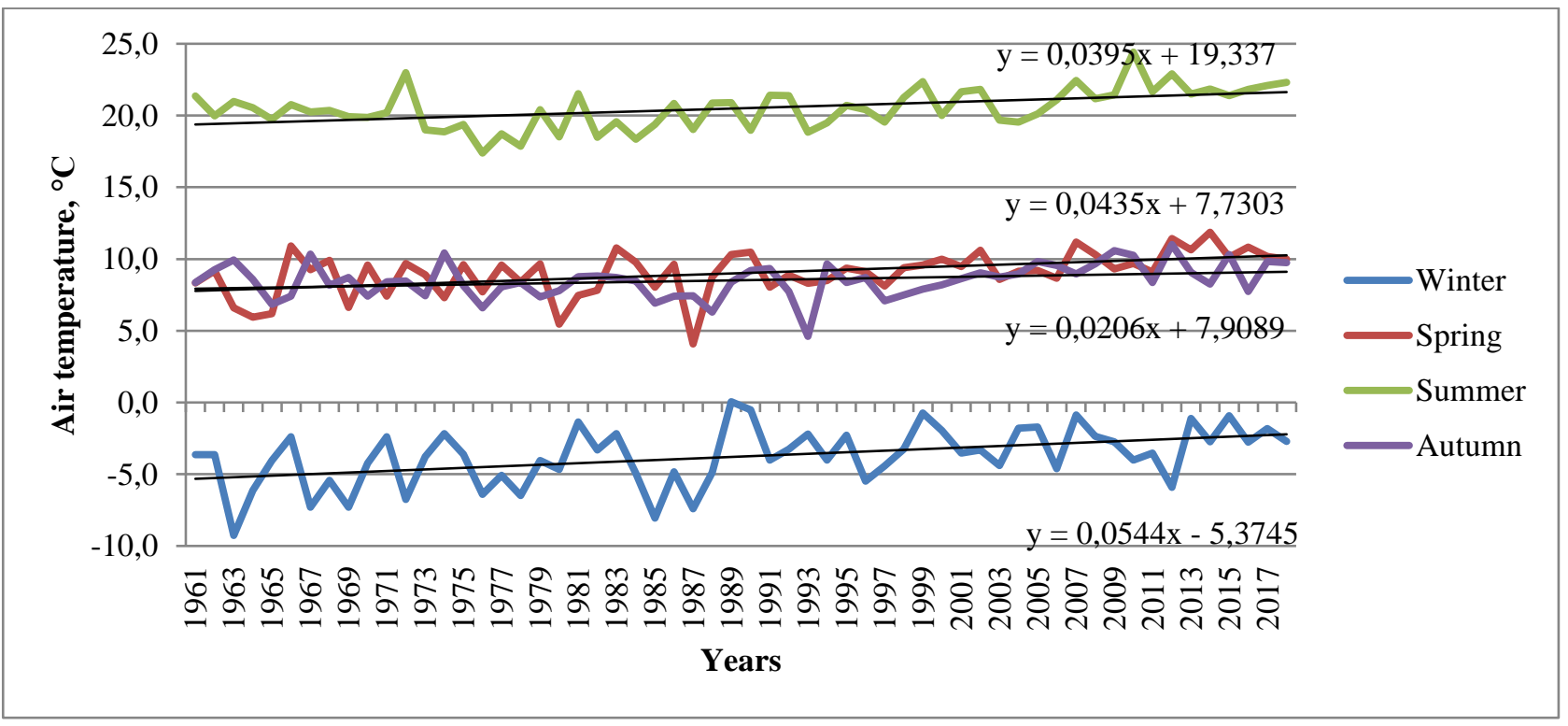

Fig. 4. Dynamics of seasonal air temperatures at the weather station Kobeliaky 


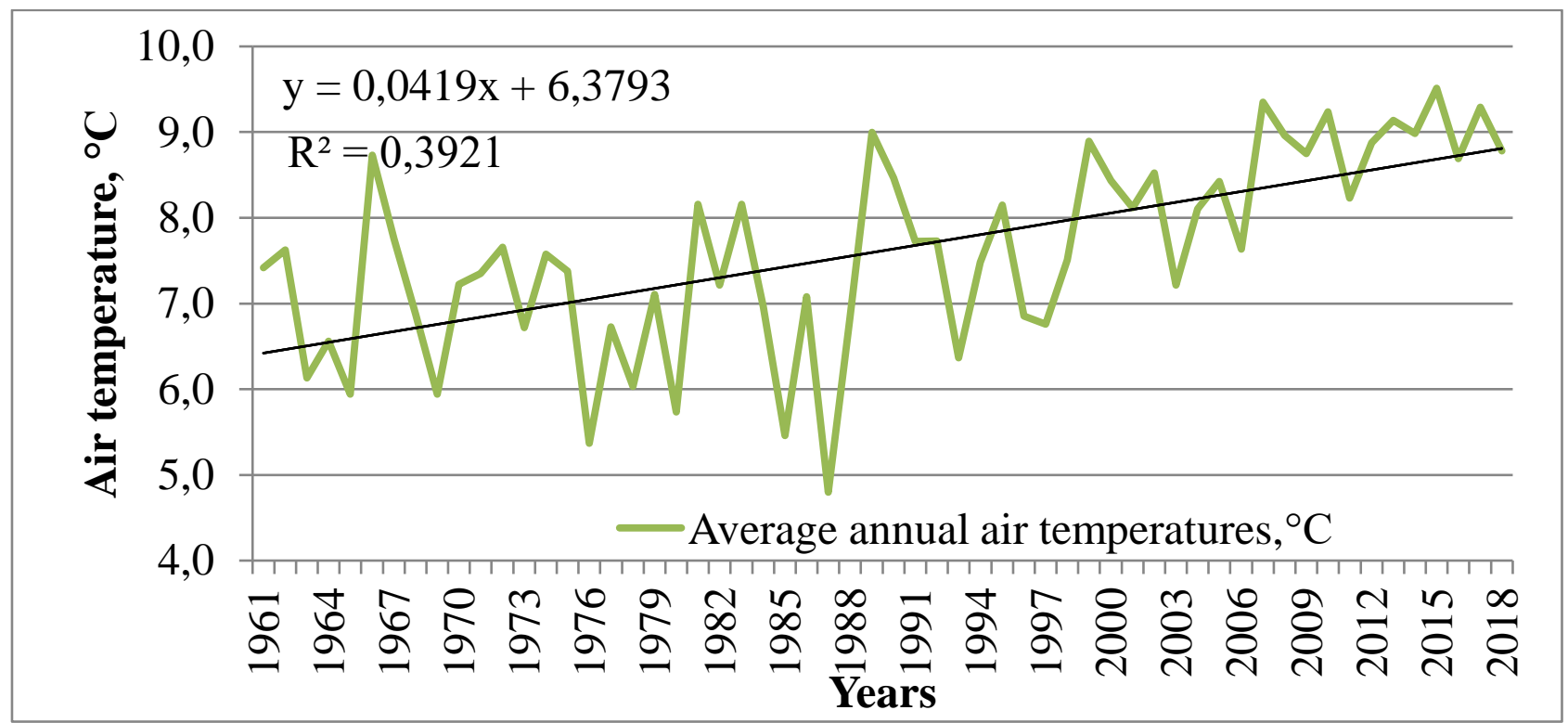

Fig. 5. Average annual air temperatures at the meteorological station Gadiach for the period 1961-2019

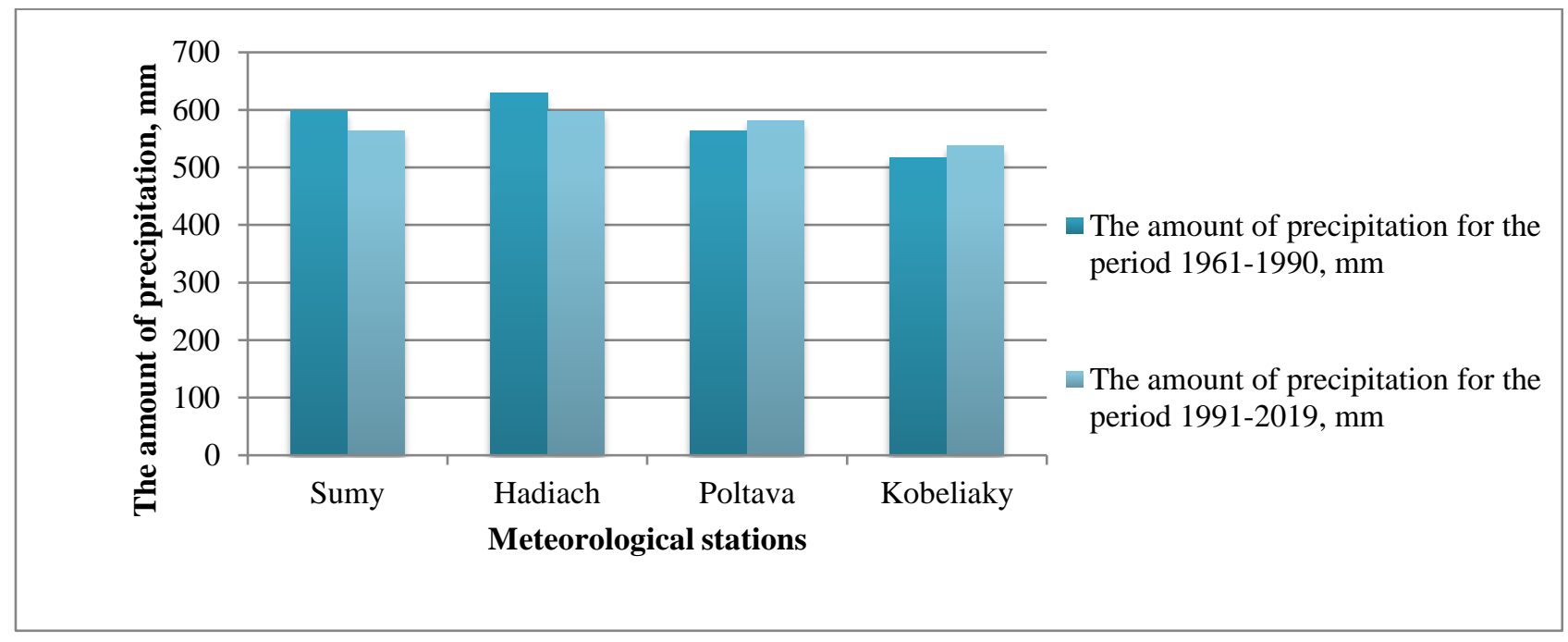

Fig.6. Dynamics of atmospheric precipitation

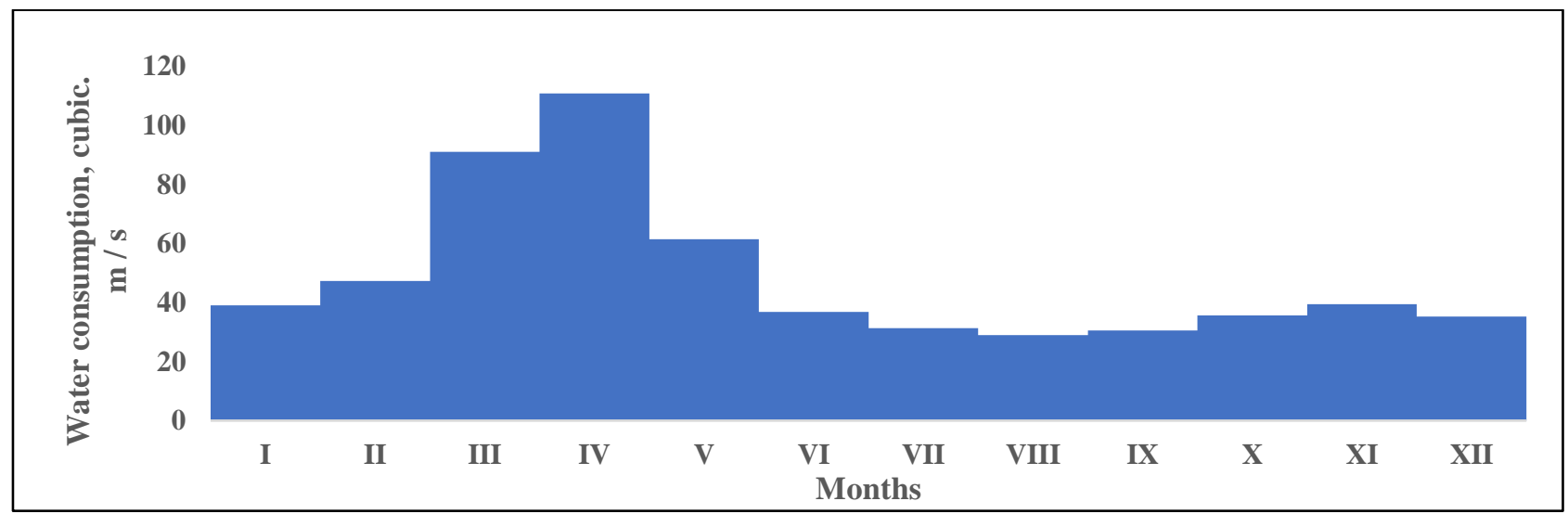

Fig. 7. Water consumption in the river Psyol at Zapsillia hydropost for the period 1961-2017 


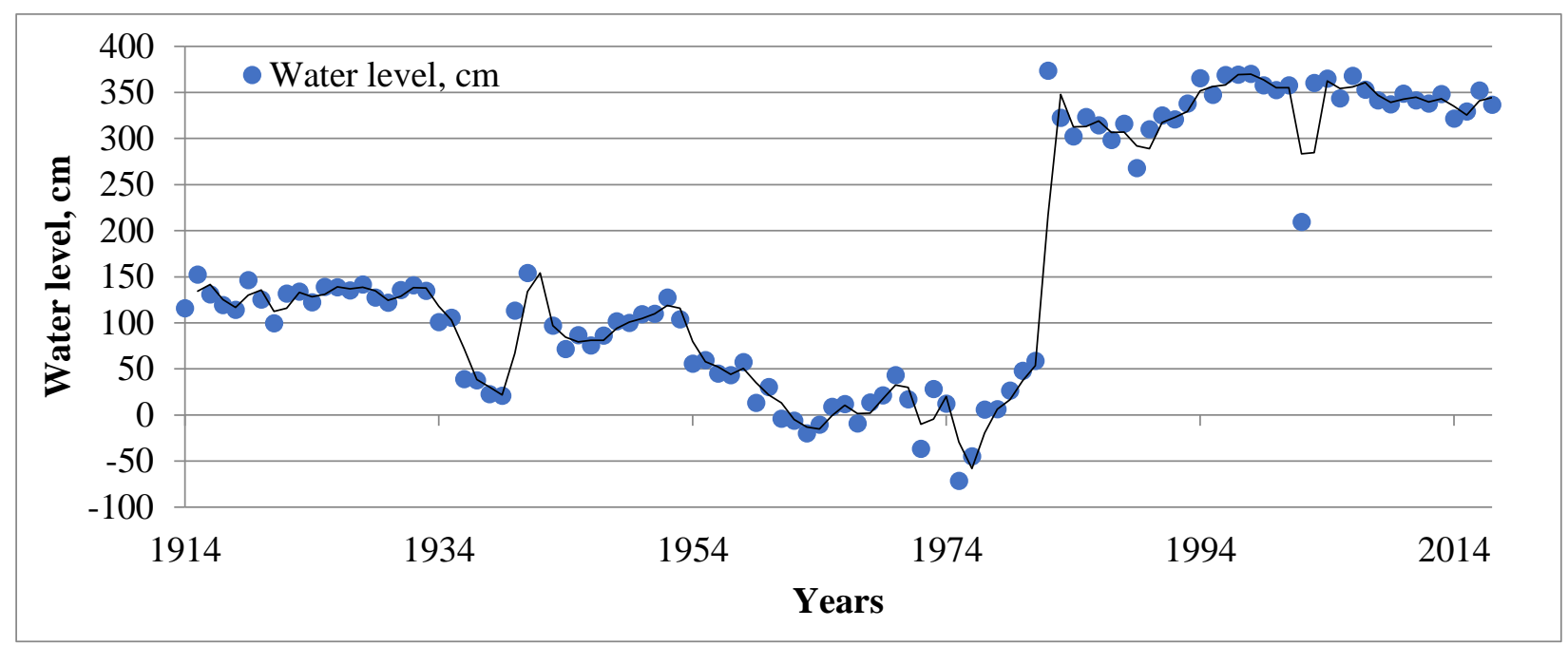

Fig. 8. Dynamics of water level at Gadiach hydropost for 1914-2017

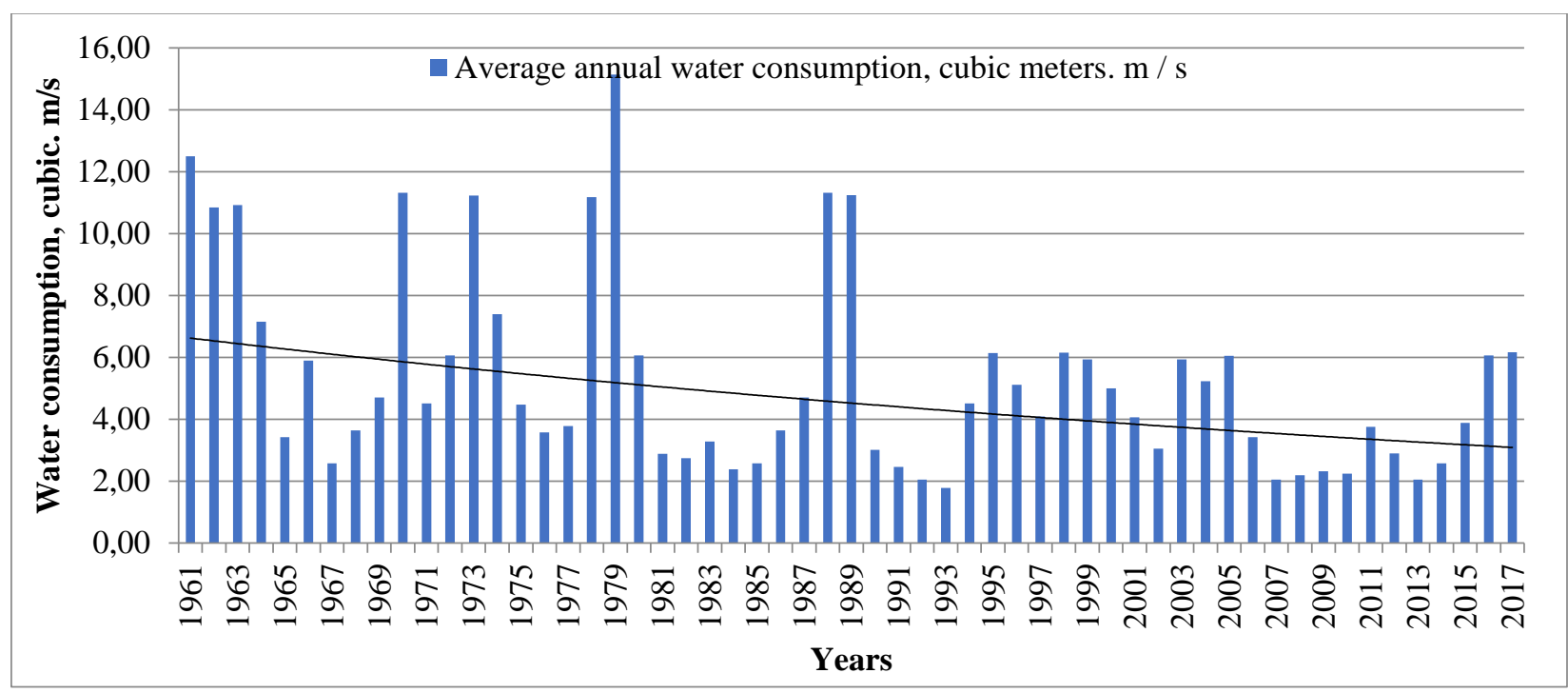

Fig. 9. Water consumption in the Govtva river (Mykhnivka hydropost)

ter consumption in the Psyol (Fig. 9) and its tributaries tends to decrease. This is probably due to the widening of the riverbed and creation of reservoirs on the river and its tributaries.

The relationship between climate change and hydrological parameters of the main watercourses in the Psyol basin was determined between air and water temperature indicators and between precipitation and water levels.

The intra-annual distribution of water temperature and its long-term dynamics has been analyzed when water bodies are mostly covered with ice in winter. In the spring rapid warming of the water surface from $0.5{ }^{\circ} \mathrm{C}$ in March to $15.0{ }^{\circ} \mathrm{C}$ in May is typical.

The summer period is characterized by maximum water temperature, while in autumn it begins to decline rapidly, in late November glaciation may begin on the rivers, lasting until late February-early March.

Indicators of average annual water temperatu- res increased mainly at all hydro posts in the study area (Fig. 10).

The calculated correlation coefficient which characterizes the relationship between air and water temperature, between precipitation and water level in the river Psyol is presented graphically (Fig. 11).

A strong relationship (Fig. 11) has been found between air and water temperature, having a different character throughout the year: a close relationship is characteristic of air and water temperatures in the summer months, as well as in March and November, i.e. in the periods when temperature is more or less stable. At the same time, during periods of active heating and cooling, the degree of correlation decreases due to its thermophysical properties, water reacts more slowly to external changes in thermal regime. In winter, the correlation coefficient is close to zero.

The correlation coefficient between precipitation and the water level in the Psyol river made it possible to detect some relationship between them: 


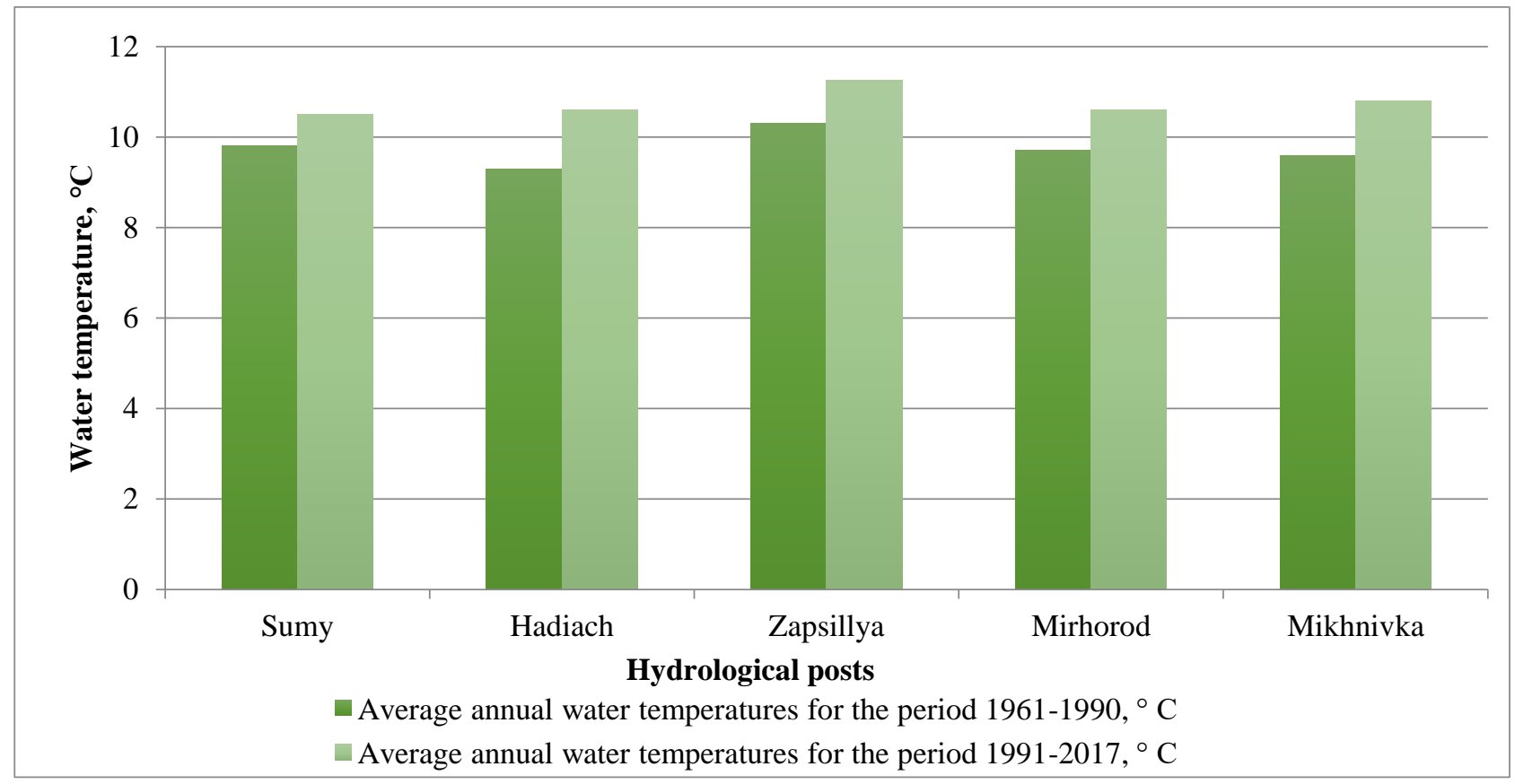

Fig. 10. Average annual water temperatures

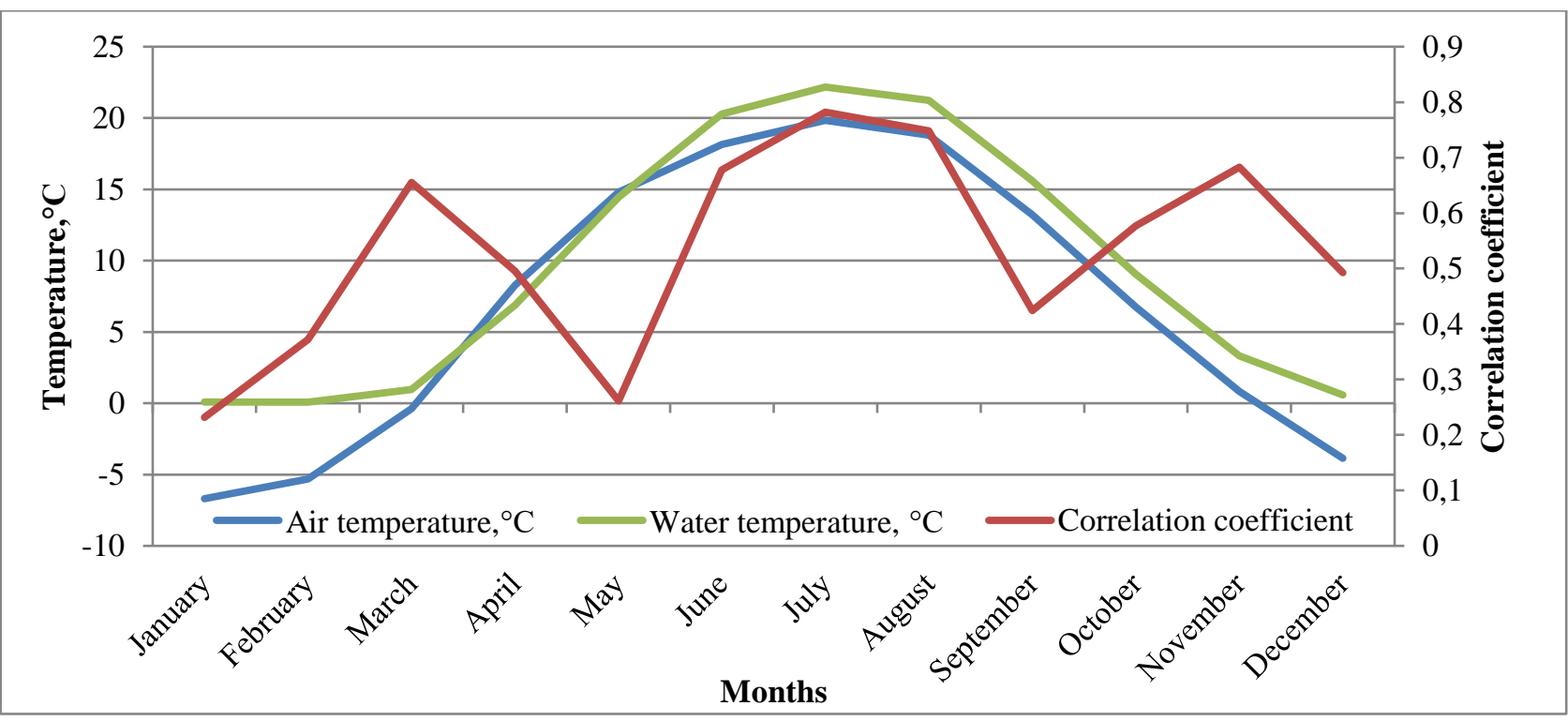

Fig. 11. Intra-annual dynamics of the correlation coefficient between air and water temperatures at meteorological stations and hydroposts in Gadiach for the period 1961-2017

the maximum value was recorded in autumn when the river runoff and, accordingly, the water level depended on precipitation. A common feature of the change in these two indicators is that the water level reaches its maximum value in early spring, while precipitation - in mid-summer. Accordingly, precipitation, which should affect the formation of the runoff, is "late" in its course and in late spring and winter the correlation coefficient takes negative values, indicating an inverse relationship. In addition, it should be remembered that the main source of the runoff in the Psyol river is water from melted snow and ice which actively fills the river during MarchApril, causing spring flooding. At the same time, maximum precipitation in summer is not accompanied by an increase in water level as evaporation from the water surface increases along with the increase in air temperature.

Rainfall increases again in winter but the water level in the river decreases at this time, especially actively during November-January. The ice phase begins and water becomes solid, while precipitation, often in the form of snow, accumulates. But in early spring its amount decreases, while after the clearing in the river the water level begins to rise.

Student's criterion was used to confirm the nonrandomness of statistical samples and the obtained correlation coefficients (Table 2). 
Student's criterion, Sumy

\begin{tabular}{|c|c|c|c|c|}
\hline Month & $\mathbf{r}$ & $\mathbf{t}$ & $\boldsymbol{\sigma}$ & $\boldsymbol{\alpha}$ \\
\hline January & 0,232 & 0,272 & 0,1336 & 57 \\
\hline February & 0,372 & 0,856 & 0,1335 & 57 \\
\hline March & 0,656 & 0,170 & 0,1336 & 57 \\
\hline April & 0,495 & 0,002 & 0,1332 & 57 \\
\hline May & 0,261 & 0,273 & 0,1297 & 57 \\
\hline June July & 0,678 & 0,839 & 0,1336 & 57 \\
\hline July & 0,782 & 0,239 & 0,1279 & 57 \\
\hline August & 0,748 & 0,258 & 0,1206 & 57 \\
\hline September & 0,423 & 0,0000745 & 0,1285 & 57 \\
\hline October & 0,577 & 0,28676 & 0,1264 & 57 \\
\hline November & 0,683 & 0,21834 & 0,1317 & 57 \\
\hline December & 0,493 & 0,00013 & 0,1304 & 57 \\
\hline Year & 0,943 & 0,000 & 0,1484 & 57 \\
\hline
\end{tabular}

According to the results of correlation coefficients calculations, it has been proved that all deviations in this statistical sample are non-random and, therefore, the value of correlation coefficients is significant.

In this study, the prognostic assessment of the future course of some climatic indicators in the Psyol river basin is applied. The main purpose of such assessment is to draw attention to the state of water bodies in the study area, to demonstrate possible results of negligent use of water resources. In addition, such an assessment is relevant in view of the global climate change that has taken place over the past 30 years and has some impact on the global ecosystem and its local manifestations. Construction of possible scenarios of air temperature and water flow in the river Psyol is relevant and important.

Considering certain trends for periods of 19611990 and 1991-2019, projections of future changes are determined, where the initial period is taken between 1991 and 2019 and the forecast period will be 2020-2048. The indicators are calculated as arithmetic averages because climatic and hydrological indicators are variable and, therefore, have a high degree of dispersion. So, it is correct to make predictions only for averages.

Based on previously analyzed data on changes in average air temperatures for the period 19912019, compared to 1961-1990, simulated indicators of air temperature growth in the Psyol river basin over the next 30 years (2020-2048) were obtained.

Given that the trends in thermal regime will remain similar to the period 1991-2019, the largest increase in air temperature is expected at the weather station Gadiach by $1.5^{\circ} \mathrm{C}$, at other weather stations this figure will range from 1.1 to $1.3^{\circ} \mathrm{C}$ (Fig. 12).

While maintaining the current trend against the background of rising air and water temperatures and declining rainfall, we find that in the coming dec- ades (2018-2044) significant water consumption is expected at the Zapsillia hydropost (in the lower reaches of the Psyol). The small rivers Khorol and Govtva are the most dehydrated, the most vulnerable to any changes in their water regime due to low gross water flow.

Taking into account the established changes in the temperature regime in the Psyol river basin, we can expect a decrease in water consumption both in the main river of the basin and in its main tributaries (Fig. 13).

In addition to changes in temperature and humidity, the reasons for this process were the shifts that occurred in the nature of intra-annual distribution of runoff. Thus, late in the XXth - early the XXI century the share of spring floods decreased as the duration of the ice phenomena period shortened and, correspondingly, the snow cover capacity on rivers decreased. Relative indicators will be a significant addition to the long-term dynamics of absolute values: in percentage terms, the most noticeable changes occurred in the tributaries of the Psyol (consumption in Govtva decreased by $39 \%$, in Khorol - by 25\%, while in Psyol -from 6 to 12\%). That is, it can be seen that small rivers, most vulnerable to any external changes, have suffered the most with the fastest evaporation, most dependent on the arrival of meltwater in the spring. A significant reduction in the duration of ice phenomena has significantly changed the water content of these rivers.

Conclusions. Changes in climatic indicators of hydrological characteristics make it possible to determine the reference conditions and classes of ecological status of rivers under anthropogenic load. Further changes with different tendencies are obvious: an increase in air temperature will cause similar changes in water temperature during the year, which may worsen water quality due to increasing concentrations of pollutants, reduced oxygen in the water; 


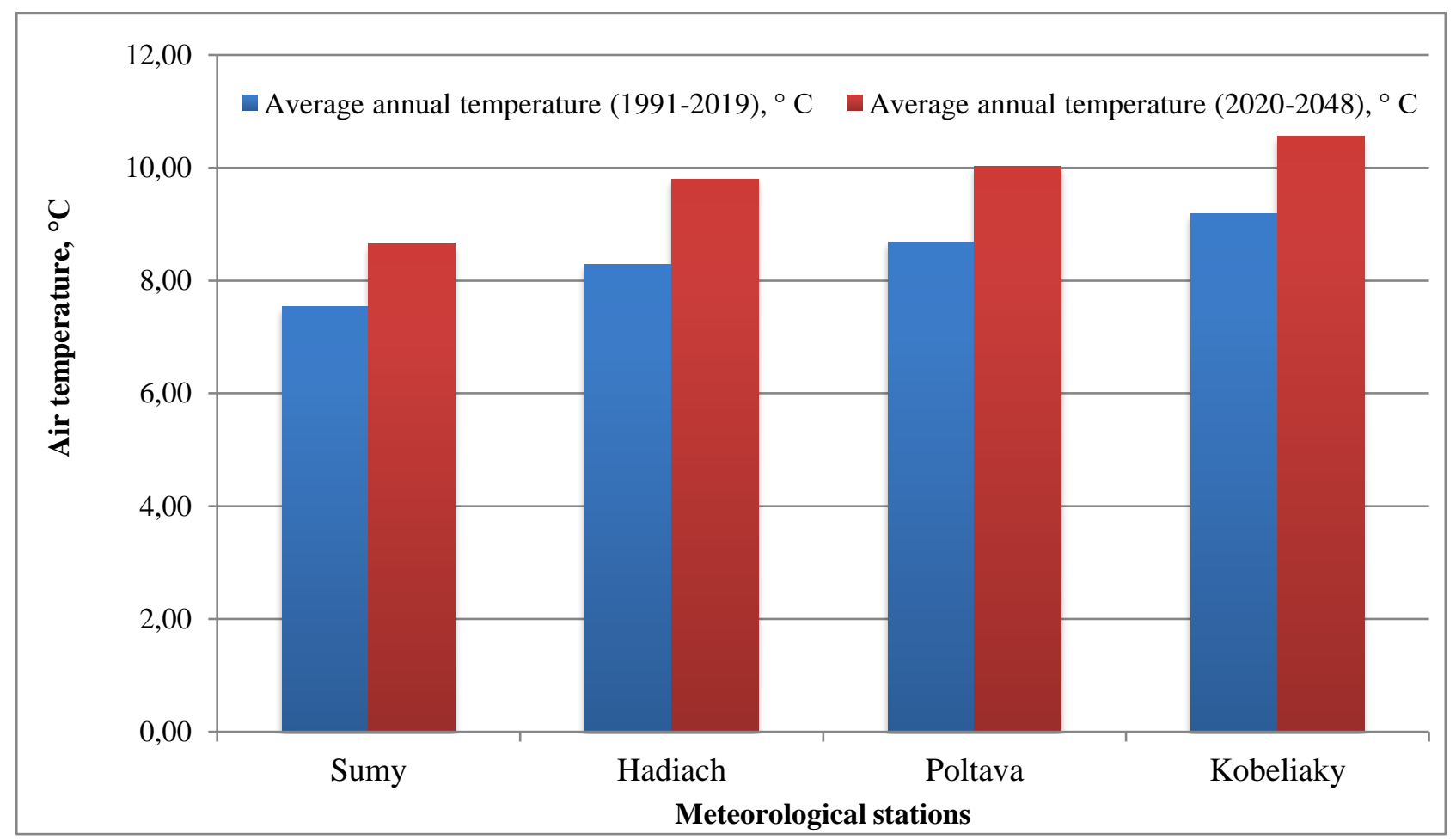

Fig. 12. Forecast average annual air temperature during 2020-2048 in the Psyol river basin

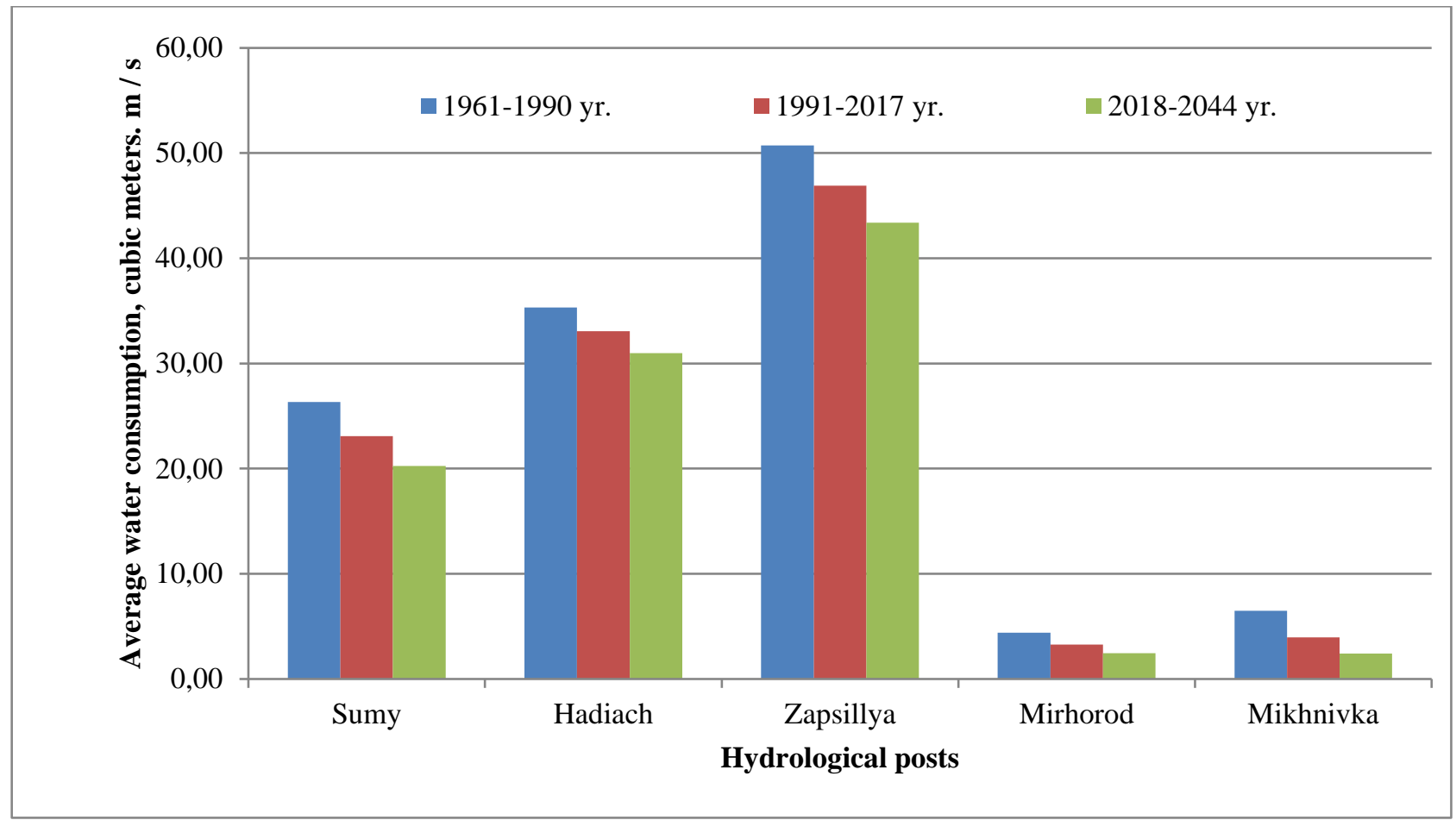

Fig. 13. Water consumption in the Psyol river basin

reduction of the duration of the ice cover, on the contrary, is aimed at improving the condition of rivers due to early melting of ice, reduction of the ice layer.

The reasons for the future shallowing of rivers in the Psyol river basin within Ukraine are presentday changes in temperature and humidity, rapid reduction in the duration of ice regime and snow cov- er in the river valley which caused the negative dynamics in water flow.

The identified patterns of changes in climatic and hydrological indicators in the Psyol river basin should be further investigated to be taken into account while planning and managing water resources, designing hydrotechnic and water intake structures. 


\section{Bibliography}

1. Водна Рамкова Директива СС 2000/60/ЄС. Основні терміни та їх визначення: Вид. офіційне. - К. : Твій формат, 2006. - 240 c.

2. Хільчевський В.К. Гідролого-гідрохімічна характеристика мінімального стоку річок басейну Дніпра / В.К. Хільчевський, І.М. Ромась, М.І. Ромась та ін. ; [За ред. В. К. Хільчевського]. - К. : Ніка-центр, 2007. - 184 с.

3. Гончарова Л.Д. Вплив Північної Атлантики на температуру повітря, опади, атмосферний тиск на лівобережній Україні / Л.Д. Гончарова, С.І. Решетченко // Украӥнський гідрометеорологічний журнал. - Одеса : TEC, 2010. - № 7. - C.54-61.

4. Гопченко Е.Д. Оиенка возможных изменений водных ресурсов Украины в условиях глобального потепления / Е.Д. Гопченко, Н.С. Лобода // Гидробиологический журнал. - Киев : Институт гидробиологии НАН Украинbl, 2000. - T. 36. - № 3. - C. 67-78.

5. Гребенюк Н.П. Нове про зміни глобального та регіонального клімату в Україні на початку XXI cm. / Н.П. Гребенюк, Т.В. Корж, О.О. Яченко // Водне господарство України. - К., 2002. - № 5-6. - С. 34-45.

6. Гребінь В.В. Сучасний водний режим річок Украӥни (ландшафтно-гідрологічний аналіз) / В.В. Гребінь. - К. : Ніка-Центр, 2010. - 316 с.

7. Лобода Н.С. Зміни клімату та їх важливі наслідки у формування якості вод (на прикладі річок Псел та Ворскла) / Н.С. Лобода, В.В. Пилип'юк // Одеса : Вісник Одеського державного екологічного університету, 2017. - № 22. - C. 69-79. Режим docmyny : http://nbuv.gov.ua/UJRN/Vodeu_2017_22_10

8. Лобода Н.С. Визначення водних ресурсів річок Псел та Ворскла з урахуванням впливу підстильної поверхні на базі моделі «клімат - стік» / Н.С. Лобода, В.В. Пилип'юк // Гідрологія, гідрохімія і гідроекологія. - К., 2015. - T. 2 (37). - C. 48-55. - Режим достуny: http://nbuv.gov.ua/UJRN/glghge_2015_2_7

9. Лобода Н.С. Расчеты и обобщения характеристик годового стока рек Украины в условиях антропогенного влияния: моногр. / Н.С. Лобода. - Одесса: Екология, 2005. - 208 с.

10. Лобода Н.С. Тендениї зміни водності та якості води річок Псел та Ворскла на початку XXI сторіччя / H.C. Лобода, В.В. Пилип 'юк // Україна: географія цілей та можливостей. - К., 2012. - Т.1. - С. 192-195.

11. Руденко В.П. Критичний екологічний стан компонентів природи в регіонах України // Український географічний журнал. - К., 2010. - № 2. - C. 60-68.

12. Loboda N.S., Pilipyuk V.V. Evaluation of ability for natural purification of the Psyol and Vorskla rivers / N.S. Loboda, V.V. Pilipyuk // International Journal of Research in Earth \& Environmental Sciences. - 2015. - N. 1-P. $28-32$.

13. Закон України 2697-VIII Про основні засади (стратегію) державної екологічної політики України на період до 2020 року: за станом на 01.01.2020 [Електронний ресурс] / Верховна рада Украӥни. - Офіu. вид. - К. : Парлам. вид-во, 2019. - Режим доступy : https://zakon.rada.gov.ua/laws/show/2697-19\#Text

14. Решетченко С.И. Влияние процессов в Северной Атлантике на климатические показатели в Украине и Восточной Европе [Електронный ресурс] / С.И. Решетченко, И.А. Кибальчич // Альманах современной науки и образования. - 2014. - №4. - C. 139-145. - Режим достуny : https://www.gramota.net/articles/issn_19935552_2014_4_38.pdf.

15. Решетченко С.І. Зміна температурного режиму на територї Харківської області [Електронний ресурс] / С.І. Решетченко, Т.Г. Ткаченко, О.Г. Лисенко // Вісник Харківського національного університету В.Н. Каразіна. - Серія: геологія, географія, екологія - Харків, 2015. - Вип. 43. - С. 153-158. - DOI : https://doi.org/10.26565/2410-7360-2015-43-24

16. Розпорядження Кабінету Міністрів України № 932-р «Про схвалення Конщепџї реалізачії державної політики у сфері зміни клімату на період до 2030 року» від 7 грудня 2016 р. [Електронний ресурс] / Кабінет Міністрів України - Режим доступу: http://www.kmu.gov.ua/control/uk/cardnpd?docid=249573705.

17. Шосте національне повідомлення Украйни з питань зміни клімату [Електронний ресурс] / Міжвідомча комісія із забезпечення виконання вимог Рамкової конвенції ООН зі зміни клімату. - 2013. - Режим доступу: http://unfccc.int/national_reports/national_communications_and_biennial_reports/submissions/items/7742.php

18. Common Implementation Strategy for the Water Framework Directive (2000/60/EC) [Електронний ресурс] / Еиropean Commission // Official Journal of the European Union. - Brussels, 2000. - Pежим доступy : https:/lec.europa.eu/environment/water/waterframework/facts_figures/guidance docs_en.htm

19. Directive 2007/60/EC of the European Parliament and of the Council of 23 October 2007 on the assessment and management of flood risks. [Електронний ресурс] / European Commission // Official Journal of the European Union. - Brussels, 2007. - Режuм docmyny : https://eur-lex.europa.eu/legal-content/EN/TXT/?uri=CELEX\% 3A32007L0060

20. IPCC, 2014: Climate Change 2014: Synthesis Report. Contribution of Working Groups I, II and III to the Fifth Assessment Report of the Intergovernmental Panel on Climate Change [Core Writing Team, R.K. Pachauri and L.A. Meyer (eds.)] [Електронний ресурс] / Intergovernmental Panel on Climate Change. - Geneva. - 151 pp. - Peжим docmyny: https://www.ipcc.ch/sitelassets/uploads/2018/05/SYR_AR5_FINAL_full_wcover.pdf

Authors Contribution: All authors have contributed equally to this work. 
UDC 556.535

Svitlana Reshetchenko

$\mathrm{PhD}$ (Geography), Associate Professor, Department of Physical Geography and Cartography, Faculty of Geology, Geography, Recreation and Tourism, V. N. Karazin Kharkiv National University, 4 Svobody Sq., Kharkiv, 61022, Ukraine, e-mail: s.reshetchenko@karazin.ua, https://orcid.org/0000-0003-0744-4272;

Sviatoslav Dmitriiev,

Bachelor, V. N. Karazin Kharkiv National University, e-mail: xa13278062@,student.karazin.ua, https://orcid.org/0000-0001-9256-6455;

\section{Nadiia Cherkashyna,}

Senior Lecturer, V. N. Karazin Kharkiv National University, e-mail: n.cherka@gmail.com, https://orcid.org/0000-0002-4066-2530;

\section{Liudmyla Goncharova,}

$\mathrm{PhD}$ (Geography), Associate Professor, Odessa State Environmental University, 5-b Ak. Glushko Av., apt. 92, Odessa, 65113, Ukraine, goncharova.luda.50@gmail.com, https://orcid.org/0000-0002-6340-2424

\section{CLIMATE INDICATORS OF CHANGES IN HYDROLOGICAL CHARACTERISTICS (A CASE OF THE PSYOL RIVER BASIN)}

Formulation of the problem. A national climate program, complying with the Association Agreement between Ukraine and the EU, is aimed at long-term adaptation measures to climate change, providing for the development of legislation in the field of environmental protection, sectoral strategies, improving air and water quality. These measures require identification of climatic factors' impact on hydrological characteristics of water bodies in any area in order to protect and improve them, as well as a comprehensive approach to the rational management of water resources.

Analysis of previous research. Using mathematical models of atmospheric circulation allows us to obtain generalized calculations of the average global and regional air temperature, characterized by significant errors in case of different models.

Problems of further research. Modern changes in climatic conditions in Ukraine are characterized by locality and rapidity: increasing number of anomalous atmospheric phenomena, frequency of droughts, dry winds which, according to preliminary estimates, may lead to reduction of water resources, changes in internal annual redistribution of water temperature and runoff against the background of increasing thermal resources of the territory.

The purpose. The article analyses climatic indicators' influence on the main hydrological characteristics on the example of the Psyol river basin within Ukraine.

Research methods. Research methods are presented by statistical and cartographic analysis (correlation analysis method). The initial information is the results of observations contained in the State Climate Cadastre and the State Water Cadastre for the Dnieper Valley.

Presentation of the main research material. Analysis of climate change in the Psyol river basin indicates a decrease in water consumption, both in the main river of the basin and in its main tributaries. In addition to changes in temperature and humidity, the reasons for this process were the shifts that occurred in the nature of the intra-annual distribution of the runoff. During the late XX - early XXI century the share of spring floods decreased due to the reduced period of ice phenomena and corresponding decrease in the thickness of the snow cover on the rivers. As a result, the most important component of the annual runoff of rivers began to decrease rapidly. The role of groundwater in the formation of water runoff increased against the background of a predominant decrease in precipitation. This is especially true for medium-size and small rivers, subject to significant anthropogenic pressure: over-regulation of channels, creation of artificial lakes, their shallowing.

Practical value. Based on the main provisions of the national environmental policy of Ukraine on the use of water resources and the implementation of European principles of the Water Framework Directive 2000/60 / EC (ERVD) the study of changes in hydrological regime of rivers is of practical importance for sustainable management.

Research results. The study of the impact of changes in climatic indicators on hydrological characteristics makes it possible to determine the reference conditions and classes of ecological status of rivers under conditions of anthropogenic pressure against the background of further changes in climatic indicators that will have different trends. 
Keywords: surface waters, inland waters, river basin, monitoring, analysis of river basins, climate, climate change, anthropogenic load.

\section{References}

1. EU Water Framework Directive 2000/60 / EC. Basic terms and their definitions: Ed. official. (2006). Kiev: Tvij format, 240. [in Ukrainian]

2. V.K. Khiltchevskiy, I.M. Romas', M.I. Romas'Hydrological and hydrochemical characteristics of the minimum runoff of rivers of the Dnieper basin. (2007). Kiev: Nika-centr, 184. [in Ukrainian]

3. Goncharova, L.D., Reshetchenko, S.I. (2010). Influence of the North Atlantic on air temperature, precipitation, atmospheric pressure on the left bank of Ukraine. Ukrayins`ky j gidrometeorologichny j zhurnal, 7, 54-61. [in Ukrainian].

4. Gopchenko, E.D., Loboda, N.S. (2000). Estimation of possible changes of water resources of Ukraine in the conditions of global warming. Gy'droby`ology`chesky`j zhurnal. Kiev: Institute of Hydrobiology of the National Academy of Sciences of Ukraine, 36, 3, 67-78. [in Ukrainian].

5. Grebenyuk, N.P. (2002). New about changes in the global and regional climate in Ukraine at the beginning of the XXI century. Water Management of Ukraine, 5-6, 34-45. [in Ukrainian].

6. Grebin, ' V. V. (2010). Modern water regime of rivers of Ukraine (landscape-hydrological analysis). Kiev: NikaCenter, 316. [in Ukrainian]

7. Loboda, N.S., Py'ly'p'yuk, V.V. (2017). Climate change and its important consequences in the formation of water quality (a case of the rivers Psyol and Vorskla). Bulletin of Odessa State Ecological University, 22, 69-79. [in Ukrainian]. Access mode: http://nbuv.gov.ua/UJRN/Vodeu_2017_22_10

8. Loboda, N. S., Py'ly'p'yuk, V. V. (2015). Determination of water resources of the rivers Psyol and Vorskla, considering influence of the underlying surface on the basis of the model "climate - runoff". Hydrology, hydrochemistry and hydroecology, 2 (37), 48-55. [in Ukrainian]. Access mode: http://nbuv.gov.ua/UJRN/glghge_2015_2_7

9. Loboda, N. S. (2005). Calculations and generalizations of characteristics of the annual runoff of rivers of Ukraine in the conditions of anthropogenic influence: monograph. Odessa: Ecology, 208. [in Russian].

10. Loboda, N.S., Py'ly'p'yuk, V. V. (2012). Trends in water content and water quality of the rivers Psyol and Vorskla at the beginning of the XXI century. Ukraine: geography of goals and opportunities, 1, 192-195. [in Ukrainian].

11. Rudenko, V.P. (2010). Critical ecological condition of nature components in the regions of Ukraine. Ukrainian Geographical Journal, 2, 60-68. [in Ukrainian].

12. Loboda, N. S., Pylypiuk, V. V. (2015). Evaluation of ability for natural purification of the Psyol and Vorskla rivers. International Journal of Research in Earth \& Environmental Sciences, 1, 28-32.

13. On basic principles (strategy) of the state ecological policy of Ukraine for the period up to 2020: Approved by the Law of Ukraine of 21.12.2010 № 2818-VI. http://zakon.rada.gov.ua/laws/show/2818-17 [in Ukrainian].

14. Reshetchenko, S.I., Kibalchich, I.A. (2014). Influence of processes in the North Atlantic on climatic indicators in Ukraine and Eastern Europe // Almanac of modern science and education, 4, 139-145. Access mode: https://www.gramota.net/articles/issn_1993-5552_2014_4_38.pdf [in Russian]. ISSN: 1993-5552.

15. Reshetchenko, S.I., Tkachenko, T.G., Ly`senko, O.G. (2015). Changing the temperature regime in the Kharkiv region. Visny`k Xarkivs`kogo nacional’nogo universy`tetu im. V.N. Karazina. Seriya: geologiya, geografiya, ekologiya, 43, 153-158. DOI : https://doi.org/10.26565/2410-7360-2015-43-24. [in Ukrainian].

16. Order of the Cabinet of Ministers of Ukraine "On approval of the Concept of implementation of state policy in the field of climate change until 2030" dated December 7, 2016, 932. Access mode: http://www.kmu.gov.ua/control/uk/cardnpd?docid=249573705. [in Ukrainian]

17. Sixth National Communication of Ukraine on Climate Change (2013). Access mode: http://unfccc.int/ national_reports/national_communications and_biennial_reports/submissions/items/7742.php [in Ukrainian].

18. Common Implementation Strategy for the Water Framework Directive (2000/60/EC). Access mode: https://ec.europa.eu/environment/water/waterframework/facts_figures/guidance docs_en.htm

19. Directive 2007/60/EC of the European Parliament and of the Council of 23 October 2007 on the assessment and management of flood risks. Access mode: https://eurlex.europa.eu/legalcontent/EN/TXT/?uri= CELEX\%3A32007L0060

20. IPCC, 2014: Climate Change 2014: Synthesis Report. Contribution of Working Groups I, II and III to the Fifth Assessment Report of the Intergovernmental Panel on Climate Change. IPCC, Geneva, Switzerland, 151. Access mode: https://www.ipcc.ch/site/assets/uploads/2018/05/SYR_AR5_FINAL_full_wcover.pdf 